\title{
The Development of Teaching Materials for Micro Teaching Assisted by Learning Videos to Improve Students' Teaching Practice Abilities
}

\author{
Suib Awrus ${ }^{1}$, Yusron Wikarya ${ }^{2}$, Wisdiarman ${ }^{3}$ and Syafei $^{4}$ \\ ${ }^{1}$ Universitas Negeri Padang, Padang, Indonesia, ه(email), suibawrus@gmail.com \\ ${ }^{2}$ Universitas Negeri Padang, Padang, Indonesia, $ه$ (email), yusronwikarya@fbs.unp.ac.id \\ ${ }^{3}$ Universitas Negeri Padang, Padang, Indonesia, $ه$ (email),wisdiarman@gmail.com \\ ${ }^{4}$ Universitas Negeri Padang, Padang, Indonesia, $\triangle$ (email), syafei.saf@gmail.com
}

\begin{abstract}
This study aims to develop teaching material for micro teaching assisted by learning video that is feasible, practical and effective which is used in lecture on micro teaching in the Fine Arts department. This research was a development study with a 4-D development model, namely define, design, develop and disseminate. Techniques of data collection were done by giving questionnaires and providing test results of learning. Data collection tools / instruments used in this study include: a device validation sheet, questionnaire and learning achievement test. The data analysis technique used in this research is descriptive quantitative and qualitative data analysis techniques, namely by describing the validity, practicality and effectiveness of teaching material in art micro teaching assisted by learning video. The result of the study shows that the teaching material for micro learning assisted by learning video are already in the category of very valid, very practical and very effective. Thus it can be concluded that the teaching material for micro teaching assisted by video learning that is developed is very valid, practical and effective is used to improve students' teaching practice abilities in micro teaching subjects.
\end{abstract}

Keywords: Development, Teaching Material, Learning Video

\section{INTRODUCTION}

Micro teaching is a teaching practice lecture that must be followed by the students of Fine Arts education study program. It is expected that the student mastery of this subject must be good, because this lecture will provide provision of one of the professional abilities that must be possessed by a teacher or prospective teacher. However, in reality, the mastery average level of students of the subject is not maximal yet, or in other words, the students learning outcomes in this subject are not as expected. The lack of the student learning outcomes in micro learning can be caused by several factors, including the source of learning and the learning media used. So far, the main learning source in Fine Arts micro learning is the lecturer itself. In teaching, the lecturer is explaining the material to the students. This means that the students only receive knowledge from the teacher's explanation, as a result, the students cannot be active and cannot learn independently because they are still fixated on the lecturer. By relying on the lecturer as a source of learning, the students have difficulty in understanding lecture material. In the learning process, the lecturer should be able to use various sources, so the students can fully master the material provided (Ministry of Education and Culture, 2013). During this time, the lecturer does not use teaching material in micro teaching lecture, but only suggests that the students can use other learning resources, such as textbooks on the market, but not all of them who want to use those books.

Like textbooks, it lacks of motivation for the students to read and the presented material is too general, the structure and sequence are not systematic and do not explain the expected competencies in micro teaching lecture. Likewise, the examples of basic teaching skills are simply demonstrated or exemplified directly by lecturer in a simple manner. Based on the problem above, it seems that the students experience problems in learning Fine Arts, namely the students cannot master these skills well so that in teaching practice, the students experience difficulties. Likewise, in the feedback activities of teaching practice, the students do not actively ask questions, do not want to express opinions, do not want to respond, cannot answer lecturer questions, and so on. The students are more silent because they have not mastered the knowledge and ways of applying basic types of teaching skills.

The problems above are caused by several factors, one of which is due to the limited reading resources and practical and effective learning media. In resolving these problems, the learning resources need to be 
developed in the form of good teaching material. Teaching material are media or learning tools that contain material, methods, boundaries of learning material, instructional activities, exercises and ways to evaluate which are designed or arranged systematically and attractively to achieve the expected competence (Hamdani, 2011). Besides it is arranged systematically, teaching material are arranged in language that is easily understood so that the students can learn independently with minimal assistance or guidance from lecturer (Prastowo, 2011).

Teaching material will be more effective if equipped with other media such as learning video. Learning video or also called Visual Audio media, because it has elements, such as $\backslash$ sound, images, motion and text (Purwanto et al, 2015).Learning video has the advantage of being able to help understand learning messages more meaningful. Besides that, by using learning video, learning outcomes will be improved, especially practical material (Awrus, 2015). This is well suited for micro learning, because the main material is the practice of applying various types of basic teaching skills. With using video media, it can be exemplified a variety of basic teaching skills.

By using the micro learning material that assisted by learning video can help the lecturer and the students in lecturing activities so that the lecturer does not present too much material. It will have a positive impact on lecturer, because some of his/her time can be devoted to guiding the student activities in practicing teaching skills. The positive impact for the students, it can reduce dependence on the lecturer and get independent learning.

Based on the problem above, it is necessary to develop teaching material in Fine Arts micro learning thatassisted by instructional video media in the form of research. With the development of instructional material that assisted by instructional video media is expected to have a considerable influence in improving the students' abilities in teaching practice. Based on the background of the problem above, this research problem can be formulated as "how to develop teaching material in art micro teaching with using video assistance that is feasible, practical and effective so that it can improve the students' ability of teaching practice in micro learning subjectat Fine Arts departement.

Based on the formulation of the problem, the specific purpose of this research is to develop teaching material in Fine Arts micro teaching that assisted by learning video to improve the ability of teaching practice of the students who are feasible, practical and effective to use in micro learning subjectat Fine Arts department.

\section{METHOD}

\section{Type of Research}

This research includes type of research and development or Research and Development

(R\&D), which research is used to produce certain product and test the effectiveness of this product (Sugiyono, 2012). The product in this study is teaching material for micro teaching assisted by learning video. The development model refers to the 4-D device development model, namely define, design, develop, and disseminate (Thiagarajan, Sivasailam, in Trianto, 2009). The research procedures to be carried out refer to these stages:

\section{a.Define Stage (Introduction)}

In this stage, researchers analyzed the needs of the lecturer and the students and analysis of curriculum / syllabus. First; analysis of the needs of the lecturer and the students, the aim is to find out problems in learning related to the learning process, the role and use of teaching material. The study program that studied does not use teaching material at all, the researchers analyze the level of needs of the lecturer and the students in the learning process when only based on general references. This analysis underlies the need for the development of Fine Arts micro learning teaching material assisted by learning video. Second; curriculum / syllabus analysis is done by paying attention to the competencies and material of what lectures are being developed in the Fine Arts department. This is done in order to the development can be in accordance to the demands of the applicable curriculum / syllabus. In this curriculum analysis, the researchers examine the syllabus of Fine Arts micro teaching subject. Activities at this planning stage will serve as guideline or reference in designing teaching material for Fine Arts micro teaching assisted by learning video.

\section{b.Design Stage (Design)}

At the design stage (design), teaching materials for micro-teaching of fine arts assisted by learning video is designed by paying attention to aspects of the design, such as; content / material aspects, presentation aspects, linguistic aspects, graphic aspects and media aspects.

\section{c.Development Stage (Development)}

This stage is the stage of testing, evaluation and revision. At the development stage, the design validation is carried out by team of experts, a revision of the design and a trial run, in order to obtain teaching material that assisted by appropriate, practical and efficient learning video. This validity test aims to see the appropriateness of content, language, graphics, media and presentation of instructional material assisted by the compiled learning video. After testing validity and it is revised, then it is carried out trial, to see whether teaching material assisted by learning video is practical and effective applied for students. In order to see the practical and effective teaching material that is carried out practicality and effectiveness test.

\section{d.Disseminate Stage;}

In this stage, the product is published through international proceeding and text book with

ISBN so that it can be used as a reference for the lecturer who teach micro learning subject in university.

\section{Methods and Data Collection Tools}

Methods of data collection are done by giving questionnaires, providing validity sheets, conducting interviews and giving test results for learning. Data 
collection tools / instruments used in this study include: a device validation sheet, interview guidelines, questionnaire and test results. The collected data is needs analysis data, expert test results data and trial results data in class. Needs analysis data from the lecturer and the students are used to find out about the need for instructional material assisted by learning video in art micro teaching subject. The expert test result data is used to answer whether the teaching material is valid or feasible, while the trial test data in class is used to answer whether the teaching material being developed is practical and effectively used in the implementation of Fine Arts micro teaching subject.

\section{Techniques of Data Analysis}

Techniques of data analysis used in this study are qualitative and quantitative descriptive, namely by describing the validity, practicality and effectiveness of micro teaching teaching material assisted by learning video.

\section{RESULT AND DISCUSSION}

As previously explanation, the purpose of this study is to develop teaching material in art micro learning assisted by learning video to improve the ability toteaching practices of the students that are feasible, practical and effective to use in micro learning subject in the Fine Arts department. For the development, the steps have been taken including; defining / introductory analysis, design, development and dissemination. The result of each of these steps can be described as follows:

\section{Defining Result or Introductory Analysis \\ a. Analysis of the Needs \\ Based on the result of interviews conducted on} Fine Arts micro teaching, the lecturer obtains information that in general the lecturer does not feel satisfied with the students learning outcomes in micro learning subject because there are still many students whose practice scores are less than standard. The methods often used by the lecturer are lectures, questions and answers and demonstrations. During this time, in introducing this type of teaching skills, the lecturer demonstrates his/herself in front of the class in a simple way. Likewise, the lack of learning resources available in the department. The learning resources used are limited to the lecturer and textbooks about micro learning. Besides that, it does not use special teaching material or it is not in accordance to syllabus or RPS, even less it is equipped by learning video. Then the information obtained from the students, they really need teaching material assisted by learning video to help them understand and practice the basic teaching skills.

\section{b. Curriculum Analysis}

Curriculum analysis aims to analyze the syllabus. This analysis is carried out to study the expected competencies / abilities and study material developed, as a basis for developing the material assisted by learning video. Based on the competencies / abilities expected and the study material developed in the syllabus, micro teaching material assisted by learning video will be developed. Based on the competencies / abilities and study material contained in the syllabus of micro learning subject, the teaching material has been assisted by learning video.

\section{Design Results}

Based on the result of the needs analysis and curriculum analysis, the next step is to design teaching material for micro learning assisted by learning video. Teaching material for Fine Arts micro teaching assisted by learning video, it has been designed with noticing to various aspects, including; content, presentation, linguistic, graphic and media aspects. The developed material in teaching material is in accordance to the material in the syllabus of micro learning subject. Likewise, the substance of the material in teaching material is logical and true. Based on the presentation aspect, it has been prepared that is, it has clear activity objective, complete structure has a cover, preface, introduction, subject matter (each subject matter has a title, indicators of success, material description, exercises and summaries), formative evaluation and References. Besides, teaching material that is designed to has complete information and systematic writing that goes along. Teaching material has been designed using clear, simple and communicative language. Teaching material has also been designed with an attractive appearance.

Besides considering aspects of teaching material above, learning video also consider aspects of the media. Learning video that is designed is in accordance to competencies can support the understanding of concepts in teaching material, consider the characteristics of the students, can guide students in practicing basic teaching skills, according to the basic components of teaching skills being trained, video is also equipped by written explanation and packaged with attractive appearance.

\section{Result of Development}

a. Validity Test

1) Validity Test of Teaching Material

The validity test of teaching material for micro learning is carried out by 4 experts consisting of 1 lecturer in the field of content / material, 1 lecturer in learning technology, 1lecturer in language expertise and 1lecturer in graphical expertise. Theaspects that are observed in teaching material are the content / material, presentation, linguistic and graphic aspect. The result of the validity test of all aspects can be seen in table 1 .

Table 1. The result of the validity test

\begin{tabular}{llll}
\hline No & Aspects & $\begin{array}{l}\text { Score/ } \\
\text { Percentage }\end{array}$ & Category \\
\hline $\mathbf{1}$ & Content / Material & $90 \%$ & Very Valid \\
\hline $\mathbf{2}$ & Serving & $88 \%$ & Very Valid \\
\hline $\mathbf{3}$ & Language & $84 \%$ & Very Valid \\
\hline $\mathbf{4}$ & Graphical & $85 \%$ & Very Valid \\
\hline & Average & $86.75 \%$ & Very Valid \\
\hline
\end{tabular}

Based on the table above, it appears that the average the validation teaching material for micro teaching 
as a whole from experts is $86.75 \%$. If it is calculated using the criteria used, the result obtained are categorized as very valid. Thus, it can be said that in terms of the content/material, presentation, linguistic and graphical aspects of micro learning teaching material that are designed are very feasible to be applied in micro learning lectures. The discussion of each aspect is as follows:

Content / material aspect; the result of the validation of teaching material from the content/ material aspect get a percentage of $90 \%$. This means that micro learning material designed, categorized as very valid in terms of content / material. This is because teaching material that is designed in accordance to the expected competencies in micro learning are adequate for achieving indicators of competency achievement, in accordance to the substance of the material and are presented systematically and logically.

Presentation aspect; the result of the validation of teaching material from the presentation aspect get a percentage of $88 \%$. This aspect is also categorized as very valid because micro learning material are designed to have a complete format. The format of the complete teaching material is to have a cover, preface, introduction, subject matter (each subject matter has a title, indicators of success, material description, exercises and summaries), formative evaluation and bibliography (Coal, 2016)). Besides teaching material that is designed to have complete information and systematic writing that goes along.

Linguistic aspect; the result of the validation of teaching material from the language aspect get a percentage of $84 \%$. This aspect is also categorized as very valid, because micro learning material is designed to use good and correct language in accordance to the rules of Bahasa. Likewise, the teaching material use clear, simple and communicative language and are in accordance to the level of student ability so that the description of the material on teaching material has good readability.Aspect of legibility(readability)is critical to the understanding of the material presented on teaching material (Kurniawati, 2015). So, micro learning material that have good legibility can direct students to understand the concept of micro learning and implement limited teaching practices properly.

The graphical aspect; the result of the validation of teaching material from the graphic aspect get a percentage of $85 \%$. This aspect is also categorized as very valid, because microlearning teaching materialis designed by using a cover design, font size and the use of an interesting layout and typography.

\section{2) Validity Test of Learning Video}

Validity test of micro teaching video is conducted by 3 experts that consisting of 1 lecturer in media, 1 lecturer in content / material expertise and 1 the lecturer in language. The aspects that observed in the learning video are media aspect, content / material aspect, and linguistic aspect. The results of the validity of the learning video for all aspects can be seen in the following table:
Table 2. Overall Validation Result

\begin{tabular}{llcc}
\hline No & \multicolumn{1}{c}{ Aspects } & Score / Percentage & Category \\
\hline $\mathbf{1}$ & Learning media & $82 \%$ & Very Valid \\
\hline $\mathbf{2}$ & Content / material & $85.71 \%$ & Very Valid \\
\hline $\mathbf{3}$ & Language & $88 \%$ & Very Valid \\
\hline & Average & $85.24 \%$ & Very Valid \\
\hline
\end{tabular}

Based on the table above, it appears that the average validation of learning video overall is $85.24 \%$. If calculated using the criteria used, the results obtained are categorized as very valid. Thus, it can be said that the learning video as a companion of micro learning teaching material is appropriate to be used for micro learning lecture, both from the aspect of media, content / material as well as from the linguistic aspect. The discussion of each aspect is as follows:

Aspect of the media; the result of the validation of micro learning video from the media aspect get a percentage of $82 \%$. This aspect is also categorized as very valid, because micro learning video is designed in accordance to the expected competencies in micro learning, supporting concepts in teaching material, considering student characteristics, guiding the students in basic teaching practice, made with an attractive appearance and the most important is in accordance with the basic skills of teaching being trained. Besides that, the learning video is equipped with a written explanation.

Content / material aspect; the result of the learning video validation from the formulated content / material aspect get a percentage of $85.717 \%$. This means that from the content / material aspect, the micro learning video that is designed, is categorized as very valid. This is because learning video is in accordance with the syllabus or RPS for art micro learning subject can encourage the students to learn independently, it can increase the students learning activities, it can support increased student knowledge and most importantly learning video is made according to the types of basic teaching skills that are available in teaching material.

Linguistic aspect; the result of the validation of learning video from the language aspect get a percentage of $88 \%$. This aspect is also categorized as very valid because micro learning video that is designed to use good and correct language in accordance to Bahasa. Likewise, learning video use clear, simple, communicative language so that they are easy to understand. Thus, the students easily understand learning material, both those are conceptual understanding and understanding of the practice of teaching basic skills.

\section{b. Practicality Test}

The main purpose of practicality testing is to see the practicality of product design. The level of practicality of this product design can be seen from the response of the students to the use of material assisted by learning video, including; ease of use, attractiveness, ease of understanding and the benefits of using teaching material micro learning assisted by learning video. For this reason, it is necessary to conduct a small-scale trial on instructional users using instructional video, namely the 
students of fine Fine Arts education study program. The result of the students response questionnaires in this smallscale trial can be seen in the following table:

Table 3: Result of the Students Questionnaire Responses toward the use of Micro Teaching Material Assisted by Learning Video

\begin{tabular}{lclc}
\hline No & Aspect & Percentage & Category \\
\hline $\mathbf{1}$ & Students responses & $88.6 \%$ & Very Practical \\
\hline
\end{tabular}

No. 1 Based on the table above, it appears that the average response of students to the practicality of teaching material micro learning assisted by learning video is $88.6 \%$. If calculated using the criteria used, the results obtained categorized as very practical. Thus, it can be said that the teaching material of micro learning assisted by learning video is already practical, both in terms of the benefits and aspects of its use. It means that this micro learning material assisted by learning video has been practically used in micro learning lecture. This is due to the fact that according to students micro learning material assisted by learning video is easy to use, clear, easy to understand and interesting, so the students feel happy and excited about learning. Based on the existence of micro learning teaching material assisted by this learning video, the students are more understanding and skilled in practicing the types of basic teaching skills.

\section{c. Effectiveness Test}

Indicators used to determine the effectiveness of the developed learning tools (instructional material assisted by learning video), namely the results of the learning outcomes test in the form of tests of practical ability to teach basic skills. The test is given after three practice teaching exercises which aim to determine the level of student ability in teaching practice. The results of the students' teaching practice ability can be seen in the following table:

\section{Table 4: The Students Practice Ability Result Value} Number Percentages

\begin{tabular}{lcc}
\hline \multicolumn{1}{r}{ Value } & Number & Percentages \\
\hline $\mathbf{8 5}-\mathbf{1 0 0}$ & 4 & 18.18 \\
\hline $\mathbf{8 1 - 8 4}$ & 16 & 72.73 \\
\hline $\mathbf{7 6}-\mathbf{8 0}$ & 2 & 9.09 \\
\hline$<\mathbf{7 6}$ & - & - \\
\hline
\end{tabular}

Based on the table above, it can be seen that from 22 students, there are 4 students $(18.18 \%)$ are getting $85-100,16$ students $(72.73 \%)$ are getting $81-84$, only 2 people who are getting below 76. This shows that in general $(90.91 \%)$ the students get very good grades, it is above 80 (Riduan, 2006). By looking at the categories of result of the student practice abilities above, it can be stated that the teaching material of micro learning assisted by learning video has been effective. Effective learning is characterized by the achievement of learning outcomes as expected, or having good grades (Guskey in Purwati
(2016). Besides the effectiveness of the products developed, because teaching material is equipped with learning video, the students do not only understand the material by reading through the material teaching, but also in depth through learning video with this learning video, the students are motivated to learn, because it is an interesting display, as well as using learning video, the students can repeat it again for unclear part, so the students really understand and can practice the types of basic teaching skills well.

\section{CONCLUSION}

Based on the result of research and discussion, it can be concluded that the micro learning teaching material assisted with learning video meets valid, practical and effective criteria to improve the ability to teaching practice of the students, so that it can be used in the micro teaching lecture process. Based on these conclusions, it is recommended to the lecturer who teach micro learning course to be able to use this assisted video in teaching material, because it is proven that it is able to improve students' teaching practice abilities.

\section{REFERENCES}

[1] Arsyad, Azhar . 2011. Media Pembelajaran. Jakarta: PT. Rajagrafindo Persada.

[2] Awrus, Suib. 2015. Pengaruh Media video Tutorial terhadap Hasil Belajar Menggambar Bentuk di Jurusan Seni Rupa. Jurnal Seni dan Desain"Ranah Seni" Volume 05, No.02, Maret 2015, hal.949-954

[3] Awrus, Suib. (2016) Pengembangan bahan ajar berbasis AndroiD pada pembelajaran Seni Budaya di SMK 4 Padang. LaporanPenelitian. JurusanSeni Rupa FBS UNP

[4] Batubara, Lolytasari. 2016. Format Penulisan Bahan Ajar. http://researchgate.net/prototipe/publication. diakses tanggal 11 Nopember 2018

[5] Pujiastuti, Heni.2016. Bahan Ajar Interaktif Berbasis Pendekatan SaiNtifik Pada Materi garis dan sudut Untuk Mahasiswa SMP. (Proseding) Seminar Nasional Matematika dan Pendidikan Matematika, UNY 2016

[6] Depdiknas. 2008. Panduan Pengembangan Bahan Ajar. Jakarta: Direktorat Pembinaan SMA, Dirjen Mandikdasmen, Depdiknas.

[7] Hamdani. (2011). Strategi BelajarMengajar. Bandung: Pustaka Setya.

[8] Kristian, Nova, dkk.2016.Pengembangan Bahan Ajar Menulis laporan Penelitian Berbasis Pengayaan Skemata Bacaan. Jurnal Pendidikan. Teori, Penelitian dan Pengembangan.Vol.1 No.2 Bulan Februari Tahun 2016. Hal.203-2013

[9] Nurmariza, Arni, Ibrahim, Muslimin dan Wahono, Widodo.2016. Pengembangan Bahan Ajar Berbasis Aktivitas Dengan Media CD Interaktif 
Pada Materi Indera Pendengaran Dan Sistem Sonar. Jurnal Pendidikan Sains Pascasarjana Universitas Negeri Surabaya. Vol. 6, No. 1, Nov 2016. Hal.1113-1122

[10] Pannen, P dan Purwanto. 2001. Penulisan Bahan Ajar. Jakarta: PAV-PPAI

[11] Prastowo A. 2011. Panduan Kreatif Membuat Bahan Ajar Inovatif. Yogyakarta: Diva Press

[12] Purwanto, Yulis dan Rizki, Swaditya. 2015. Pengembangan Bahan Ajar Berbasis Kontekstual Pada Materi Himpunan Berbantu Video Pembelajaran. Aksioma, Jurnal Pendidikan Matematika FKIP Univ. Muhammadiyah MetroVol. 4, No. 1 (2015) 67-77

[13] Purwati, Heni,dkk.2016. Pengembangan Bahan Ajar Mata Kuliah Pengembangan Media Pembelajaran Menggunakan Macro Media Flash Professional 8. Jurnal Derivat Volume 3 No. 1 Juli 2016, hal. 15-24

[14] Riduan. 2006. Belajar Mudah Penelitian Untuk Guru, Karyawan dan Peneliti Pemula. Bandung: Alfabeta

[15] Sapta, A. 2009. Pengembangan Bahan Ajar. (online) (http://andysapta. blogspote.com/2009/01/pengembangan bahan ajar 5.httml, diakses 14 Januari 2016

[16] Trianto. 2009. Mendesain Model Pembelajaran Inovatif Progresif. Jakarta: Prenada Media Group 